\title{
Alternative macrophage activation and the regulation of metabolism
}

\author{
Paul Webb
}

Address: Methodist Hospital Research Institute, Center for Diabetes Research, 6565 Fannin Street, F8-045, Houston, TX 77030, USA

Email: pwebb@tmhs.org

FI000 Biology Reports 2009, I:2 (doi: 10.34I0/BI-2)

The electronic version of this article is the complete one and can be found at: http://FI000.com/Reports/Biology/content/I/2

\begin{abstract}
Macrophages are white blood cells that have important roles in phagocytosis and immune responses. A series of recent papers reveals that nuclear receptors influence the precise pathway of macrophage phenotype polarization and that these effects protect against insulin resistance and metabolic syndrome, the most important group of diseases facing the industrialized world.
\end{abstract}

\section{Introduction and context}

Obesity and insulin resistance are often accompanied by low-grade systemic inflammation, and these seemingly disparate phenomena are linked by adipose tissue macrophages (ATMs) [1]. Macrophages are derived from circulating monocytes that migrate into target tissues [2]. Histological analysis reveals striking macrophage infiltration into the white adipose tissue (WAT) of obese and insulin-resistant individuals and this is coupled to expression of inflammatory genes $[3,4]$. The relationship between insulin resistance and macrophagemediated inflammation is causal and not simply correlative. Mice with disruptions in genes that mediate monocyte infiltration (for example, genes encoding the chemokine MCP-1 and the chemokine receptor CCR2) and the macrophage inflammatory response (for example, genes encoding the cytokine TNF $\alpha$, the TNF receptor, the kinase JNK, and the NF-kB inhibitor kinase $\operatorname{Ikk} \beta$ ) improved metabolic profiles, and high doses of antiinflammatory salicylates improve insulin sensitivity in humans [5].

Peroxisome proliferator-activated receptor gamma $(\operatorname{PPAR} \gamma)$ is a nuclear receptor that is activated by fatty acids, and recent discoveries have focused attention on its role in the polarization of macrophage phenotype [6]. It is now known that macrophage phenotype varies greatly in a manner that is influenced by local microenvironment: classically activated M1 macrophages are recruited to sites of infection and tissue damage, where they engulf debris and trigger adaptive immune responses, whereas alternatively activated M2 macrophages limit local inflammatory responses and promote tissue repair [7]. PPAR $\gamma$ is best known for its influence on adipocyte development and as the target for insulin-sensitizing drugs, the thiazolidinediones [8]. However, PPAR $\gamma$ also exerts a widespread influence on macrophage biology [8-10]; PPAR $\gamma$ activators repress pro-inflammatory genes, stimulate transcriptional cascades that promote cholesterol export from foam cells (lipid-laden macrophages) in atherosclerotic plaque and inhibit macrophage infiltration into WAT. In 2007, two groups made the remarkable observation that PPAR $\gamma$ is required for M2 macrophage polarization [6,11]. Equally surprisingly, PPAR $\gamma$-dependent M2 polarization protects against insulin resistance and other aspects of metabolic syndrome. Mice with macrophage-specific PPAR $\gamma$ gene disruptions exhibit increased obesity on high-fat diets and many of the hallmarks of systemic insulin resistance, including altered capacity for glucose uptake and oxidative phosphorylation in skeletal muscle $[6,12]$.

\section{Major recent advances}

How does disruption of the PPAR $\gamma$ gene in macrophages influence insulin resistance and obesity? Because M2 polarization inhibits local inflammatory responses, it 
Figure I.

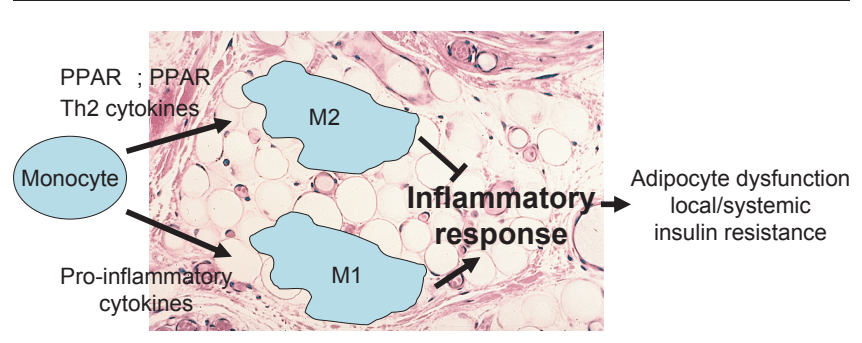

Monocytes that enter adipose tissue develop into adipose tissue macrophages (ATMs) that can be polarized in two ways: M2 macrophages respond to local Th2 cytokines to limit the inflammatory response, whereas $\mathrm{MI}$ macrophages respond to local pro-inflammatory stimuli to promote local inflammatory responses and alter local adipocyte function. The peroxisome proliferator activated receptors PPAR $\gamma$ and PPARQ both promote M2 polarization; PPAR $\gamma$ plays incompletely defined roles in activation along the M2 pathway, whereas PPAR区 is required for elaboration of the M2 phenotype.

seems likely that PPAR $\gamma^{-1}$ macrophages secrete inflammatory cytokines that alter adipocyte function (Figure 1). Accordingly, Odegaard and colleagues find increased expression of inflammatory markers in adipose tissue in the macrophage-specific PPAR $\gamma$-knockout mice [6]. This effect is coupled to suppression of multiple genes involved in adipocyte function and insulin response, and co-culture experiments confirm that PPAR $\gamma^{-1-}$ macrophages produce secreted factors that limit insulin sensitivity in adipocytes. Overall, changes in adipocyte function are likely to alter secretion of multiple adipocyte hormones that affect the systemic insulin response. In addition, reduced fat storage in adipose tissue depots will probably be coupled to increased accumulation of lipids in liver, skeletal muscle and other locations with known inhibitory effects on insulin sensitivity in these tissues. PPAR $\gamma$-dependent M2 polarization might also exert direct effects on other tissues: Hevener and colleagues [12] find that hepatic insulin sensitivity varies with the extent of PPAR $\gamma^{-1-}$ macrophage infiltration into liver.

Two recent studies have highlighted an equally important role for another PPAR subtype (PPAR $\gamma$ ) in alternative macrophage activation and insulin resistance $[13,14]$. PPAR $\gamma$ is highly expressed in macrophages and is implicated in transcriptional repression of atherogenic inflammation [15-17]. It is also known that alternative macrophage activation is associated with fatty acid $\beta$-oxidation and oxidative metabolism [18]: classic effects of PPAR $\gamma$. Both studies confirm that PPAR $\gamma$ is required for expression of $\mathrm{M} 2$-specific genes and show that mice with macrophage-specific PPAR $\gamma^{-1-}$ knockouts develop systemic insulin resistance and hepatic steatosis. Results are not in complete agreement; Odegaard et al. [13] find that macrophage-specific PPAR $\gamma$ knockouts mainly affect hepatic insulin sensitivity via influences on polarization of resident liver macrophages (Kupffer cells), whereas Kang et al.[14] observe prominent effects on ATMs, reductions in adipose tissue insulin sensitivity and adipocyte lipolysis. These discrepancies may be related to the nature of the mouse knockout model, but it should be emphasized that they do not detract from the main conclusion; $\operatorname{PPAR} \gamma$ protects against insulin resistance via effects on M2 macrophage polarization.

The papers also point towards roles for cross-talk between resident macrophages and host tissues in local inflammation and development of insulin resistance $[13,14]$. Kang et al. [14] find that adipocytes and hepatocytes produce helper T-cell (Th2)-type cytokines (IL-4 and IL-13) which prime macrophages along the M2 pathway to limit local inflammatory response; in fact, IL-4 enhances PPAR $\gamma$ expression, directly linking IL-4 signaling to the PPAR $\gamma$ pathway. Both groups find that PPAR $\gamma^{-1-}$ macrophages secrete paracrine factors that promote adipocyte and hepatocyte dysfunction in coculture experiments. These observations raise the interesting possibility that alterations in resident macrophage polarization lead to runaway derangements in tissue/ macrophage interactions in MSX. As macrophages acquire pro-inflammatory characteristics they will alter cytokine secretion in surrounding tissues to trigger further inflammatory responses and production of factors that inhibit local and systemic insulin responses.

\section{Future directions}

In summary, the fascinating implication of this series of papers is that strategies that promote $\mathrm{M} 2$ macrophage polarization will cure systemic insulin resistance and prevent MSX. Much remains to be learned. There are actually multiple M2 macrophage types with incompletely defined functions [7]; it is not clear whether all M2 subtypes protect against insulin resistance and MSX. It is also not clear that M2 macrophages are always beneficial, as they are implicated in tumor inflammation and fibrosis [1]. It is also likely that macrophage nuclear receptors will be attractive targets for drugs that influence macrophage polarization and insulin resistance; PPAR $\gamma$ and PPAR $\gamma$ have proven beneficial effects and about half of the members of the nuclear receptor gene family are expressed in macrophages [19]. Dissecting the actions of nuclear receptors in macrophage biology is likely to become an even more fertile area of research in the next few years. 


\section{Abbreviations}

ATM, adipose tissue macrophage; CCR2, chemokine receptor 2, I $\kappa \mathrm{B}$, inhibitor of $\mathrm{NF}-\kappa \mathrm{B}$; IL, interleukin; IR, insulin resistance; JNK, Jun kinase; MCP-1, monocyte chemoattractant protein 1; MSX, metabolic syndrome/ syndrome $\mathrm{X}$; NR, nuclear receptor; PPAR, peroxisome proliferator activated receptor; $\mathrm{TNF} \alpha$, tumor necrosis factor $\alpha$; TNFR, tumor necrosis factor receptor; WAT, white adipose tissue

\section{Competing interests}

The author declares that he has no competing interests.

\section{References}

I. Hotamisligil GS: Inflammation and metabolic disorders. Nature 2006, 444:860-7.

FI000 Factor 9.0 Exceptional

Evaluated by Marc Jeschke 25 Apr 2008

2. Taylor PR, Martinez-Pomares L, Stacey M, Lin HH, Brown GD, Gordon S: Macrophage receptors and immune recognition. Annu Rev Immunol 2005, 23:901-44.

3. Xu H, Barnes GT, Yang Q, Tan G, Yang D, Chou CJ, Sole J, Nichols A, Ross JS, Tartaglia LA, Chen $\mathrm{H}$ : Chronic inflammation in fat plays a crucial role in the development of obesity-related insulin resistance. J Clin Invest 2003, I I 2: | 82 I-30.

FI000 Factor 6.0 Must Read

Evaluated by Giorgio Berton 14 Jan 2004

4. Weisberg SP, McCann D, Desai M, Rosenbaum M, Leibel RL, Ferrante AW Jr: Obesity is associated with macrophage accumulation in adipose tissue. J Clin Invest 2003, I I 2: I796-8.

FI000 Factor 6.0 Must Read

Evaluated by Giorgio Berton 14 Jan 2004

5. de Luca C, Olefsky JM: Inflammation and insulin resistance. FEBS Lett 2008, 582:97-105.

6. Odegaard JI, Ricardo-Gonzalez RR, Goforth MH, Morel CR, Subramanian V, Mukundan L, Eagle AR, Vats D, Brombacher F, Ferrante AW, Chawla A: Macrophage-specific PPARgamma controls alternative activation and improves insulin resistance. Nature 2007, 447: I I 16-20.

FI000 Factor 9.6 Exceptional

Evaluated by P'ng Loke 7 Jun 2007, Paul Webb 7 Feb 2008

7. Mantovani A, Sica A, Sozzani S, Allavena P, Vecchi A, Locati M: The chemokine system in diverse forms of macrophage activation and polarization. Trends Immunol 2004, 25:677-86.

8. Tontonoz P, Spiegelman BM: Fat and beyond: the diverse biology of PPARgamma. Annu Rev Biochem 2008, 77:289-312.
9. Valledor AF, Ricote $\mathrm{M}$ : Nuclear receptor signaling in macrophages. Biochem Pharmacol 2004, 67:201-I2.

10. Zhang L, Chawla A: Role of PPARgamma in macrophage biology and atherosclerosis. Trends Endocrinol Metab 2004, 15:500-5.

II. Bouhlel MA, Derudas B, Rigamonti E, Dièvart R, Brozek J, Haulon S, Zawadzki C, Jude B, Torpier G, Marx N, Staels B, Chinetti-Gbaguidi G: PPARgamma activation primes human monocytes into alternative $\mathrm{M} 2$ macrophages with anti-inflammatory properties. Cell Metabolism 2007, 6:137-43.

12. Hevener AL, Olefsky JM, Reichart D, Nguyen MT, Bandyopadyhay G, Leung HY, Watt MJ, Benner C, Febbraio MA, Nguyen AK, Folian B, Subramaniam S, Gonzalez FJ, Glass CK, Ricote M: Macrophage PPAR gamma is required for normal skeletal muscle and hepatic insulin sensitivity and full antidiabetic effects of thiazolidinediones. J Clin Invest 2007, I I 7:1658-69.

13. Odegaard Jl, Ricardo-Gonzalez RR, Red Eagle A, Vats D, Morel CR Goforth MH, Subramanian V, Mukundan L, Ferrante AW, Chawla A: Alternative M2 activation of Kupffer cells by PPARdelta ameliorates obesity-induced insulin resistance. Cell Metabolism 2008, 7:496-507.

FI000 Factor 6.0 Must Read

Evaluated by Paul Webb 2 Jul 2008

14. Kang K, Reilly SM, Karabacak V, Gangl MR, Fitzgerald K, Hatano B, Lee $\mathrm{CH}$ : Adipocyte-derived Th2 cytokines and myeloid PPARdelta regulate macrophage polarization and insulin sensitivity. Cell Metabolism 2008, 7:485-95.

FI000 Factor 6.0 Must Read

Evaluated by Paul Webb 2 Jul 2008

15. Lee CH, Chawla A, Urbiztondo N, Liao D, Boisvert WA, Evans RM, Curtiss LK: Transcriptional repression of atherogenic inflammation: modulation by PPARdelta. Science 2003, 302:453-57.

16. Barish GD, Atkins AR, Downes M, Olson P, Chong LW, Nelson M, Zou Y, Hwang H, Kang H, Curtiss L, Evans RM, Lee CH: PPARdelta regulates multiple proinflammatory pathways to suppress atherosclerosis. Proc Natl Acad Sci USA 2008, I 05:427|-6.

17. Takata $Y$, Liu J, Yin F, Collins AR, Lyon C], Lee $\mathrm{CH}$, Atkins AR, Downes M, Barish GD, Evans RM, Hsueh WA, Tangirala RK: PARdelta-mediated antiinflammatory mechanisms inhibit angiotensin II-accelerated atherosclerosis. Proc Natl Acad Sci USA 2008, 105:4277-82.

18. Vats D, Mukundan L, Odegaard Jl, Zhang L, Smith KL, Morel CR, Wagner RA, Greaves DR, Murray PJ, Chawla A: Oxidative metabolism and PGC-Ibeta attenuate macrophagemediated inflammation. Cell Metabolism 2006, 4:13-24.

FI000 Factor 3.0 Recommended

Evaluated by Dominique Langin 25 Oct 2006

19. Barish GD, Downes M, Alaynick WA, Yu RT, Ocampo CB, Bookout $A L$, Mangelsdorf DJ, Evans RM: A nuclear receptor atlas: macrophage activation. Mol Endocrinol 2005, 19:2466-77. 